
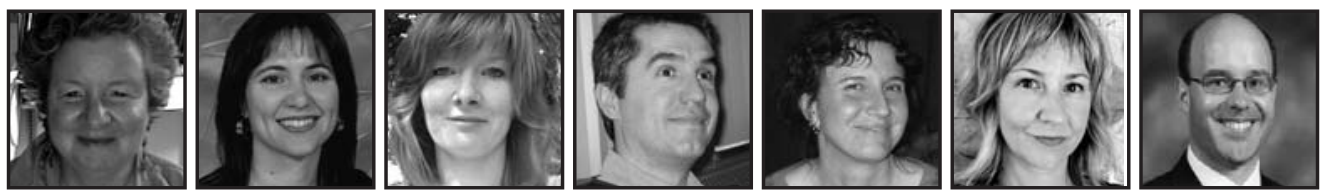

\title{
Line Up Your Ducks! Teachers First!: Teachers and Students Learning With Laptops in a Teacher Action Research Project
}

\author{
Teresa Strong-Wilson, McGill University \\ Manuela Pasinato, St. Willibrord School \\ Kelly Ryan, St. Willibrord School \\ Bob Thomas, New Frontiers School Board \\ Nicole Mongrain, McGill University \\ Maija-Liisa Harju, McGill University \\ Richard Doucet, Selwyn House School
}

\section{ABSTRACT}

Teachers are increasingly expected to incorporate technology into their practices. However, they need experiences with using new technologies in their classrooms and support to talk about and reflect on those experiences. "Teachers first" was one of the main principles that Lankshear and Synder (2000) identified as key to teachers incorporating new technologies into their practice. To put this principle into place, you need to "line up your ducks": there needs to be a structure, sustained support for that structure, and opportunities for active teacher participation. This article links findings from the first year of the "Learning with Laptops" project by focusing on the most experienced "teacher learners" and connects it with the research literature on teacher and student engagement. The findings contribute support for the principle: teachers (as learners) first!

"...a teacher teaches you how to learn principally by learning himself [sic]." (Gatto, 2000 cited in Burrington \& Sortino, 2004, p. 227) 


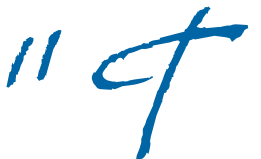

eachers first." It may seem strange to begin with this statement in a journal issue devoted to student engagement. The assertion comes from Colin Lankshear and Bill Synder (2000, p. 61), who investigated how Australian teachers were integrating new technologies into their classrooms. Over and over, they heard the same refrain: if teachers lacked support for resources or knowledge, change was unlikely. They concluded that teachers, themselves, needed first to be involved in authentic learning experiences with new media in order to also engage their students. Student engagement hinges on teachers feeling part of a learning process with, or alongside their students; this was one of the findings in an issue of a journal on student engagement (Portelli \& Butler-Kisber, 2003). "Teachers first" was also one of the most significant outcomes of the research that is the subject of this paper.

The study is based on a teacher action research partnership project, "Changing Literacies and Changing Formations" (CLCF) through "Learning with Laptops" (LWL), in which seven teachers gather together once a month as well as participate in a teacher blog to share what they are learning as they integrate laptop computers into their classroom practice. ${ }^{1}$ Teacher action research involves teachers, on their own and/or with academics, in systematic inquiry on an issue or a question of significance to them and/or their students (Dewey, 1933; Kemmis \& McTaggar, 2000); moreover, teachers are uniquely positioned to generate the kind of knowledge that will directly inform practice (Cochran-Smith \& Lytle, 1993).Two elements have been key to teacher engagement in the project: a supportive social context and sustained opportunities to experience, and experiment with, new technologies in the classroom.

The idea of the teacher as a learner challenges the traditional notion that the teacher is the only, or main, expert in the classroom. It brings into question the traditional divide between teacher education and professional development, which Cochran-Smith and Zeichner (2005), in their review of teacher education, also challenge. Do teachers continue to learn after they complete their schooling and university training? Yes, they do, and the research confirms this, whether we look at teachers as researchers (Cochran-Smith \& Lytle, 1993; Katch, 2001; Kincheloe, Slatterly \& Steinberg, 2000; Paley, 1981,2004) or recent scholarship on teachers learning in social contexts and forming professional learning communities (Burrington \& Sortino, 2004; Butler et al., 2004; Glazer, Abbott \& Harris, 2004; Henson, 2001; Jenlink \& KinnucanWelsch, 2001; Pianfetti, 2001; Strong-Wilson, 2007). 
Wheatley (2002) maintains that "human beings have always sat in circles and councils to do their best thinking" (p. 9). In the company of others, we can summon the courage to face change, and be creative in the process. Given the increasing pressure on teachers to incorporate technology within their practice (Russell, Bebell, O'Dwyer \& O'Connor, 2003; Statistics Canada, 2004) and the shifting of a dominant print literacy into an electronic and multimodal one, teachers need opportunities to gather together as one story world passes into the building of another one (Mackey, 2006). Whereas teachers' literacy formations have largely occurred through encounters with the oral and written word (Brandt, 1992; Brown, 1999), as well as through television (Gee, 2003), students bring literacy formations that differ from those of their teachers. As Mackey $(2002,2003)$ has documented, young people are reading multiple "texts," including books and television, but also CD-ROMs, DVDs, video games, and the Internet. With literacy formations changing, childhoods are also undergoing transformation (Buckingham, 2000; Jones, Williams, \& Fleuriot, 2003). Individuals tend to become deeply attached to the experiences that formed an integral, and positive, part of growing up, and that in adulthood, become interwoven with reveries of an idealized childhood (Chawla, 1994; Goodenough, 2004; Philo, 2001; Strong-Wilson, 2006). Because "what counts as evidence of literate competence is a key issue in determining children's futures in a democratic society" (Meek, 2004, p. 308), teachers need to open themselves to new possibilities. The most experienced person is not someone who has acquired the most expertise; it is someone who can be "radically undogmatic" so as to bring beliefs and practices into question and open herself to new experiences (Gadamer, 1975/1998, p. 355).

The current research project is based upon the principle of actively involving teachers in the changes that affect their classrooms. The project is presently entering its second year, with data collection and analysis still under way; this next year (2007-2008) will focus on the relationship between teacher and student engagement in learning. However, we believe that enough evidence has been accumulated to show the importance of "teachers first" in engaging students with new technologies that we share some of it here. In the process, we attempt to reproduce the importance of teacher conversation in the research, focusing on one of the school teams: Kelly and Manuela. Consistent with the argument in this article, Kelly and Manuela have been teacher learners the longest in the project, having been with "Learning with Laptops" since its inception in 2004. We also highlight the reflections of Bob Thomas, the pedagogical technology expert, who has been leading the teachers in the LWL project. 


\section{Teacher Conversation}

K: (Kelly) It started with me because I'd previously been the computer teacher for a year and I had some background knowledge ... and I remember thinking, 'Yes that could be interesting, but who would I do it with?'-I would have to have a partner. I wasn't Manuela's partner at the time. And approaching her and saying,'Hey, have a look at this. You like computers too, or you're starting to get into that kind of computer mode, and ...'

M: (Manuella) Yes, the reason I joined is because Kelly asked me and because ... well, the first reason is because I really respected her as a teacher. I felt that I could trust her. Because I didn't know her much, but I wouldn't have associated with a teacher on a projects tht I didn't think I could work with, so that was the first reason. And the other big motivator for me was that I knew nothing of computers. I just knew how to prepare a Word document ...

K: You had a beginning fascination with computers ... because you would ask me-

M: Oh, no. That's why - I had the desire to learn, that's what started it because all I could do was type up an exam, to see the information that the kids retained, and I thought, that's not what it's about, and I had been trying to incorporate it in class but I never was successful. I didn't know how and I didn't have anyone helping me. Like I always say, I went through so many stages and that's why this is a good opportunity, I trust Kelly and it looks like an interesting project, and she knows more than me, she'll help me ... (laughing) (Kelly \& Manuela, interview, April 12, 2007)

\section{Line Up Your Ducks}

Jim is a firm believer. We're all believers, I suppose, in the sense that we really feel that there is some potential to facilitate learning, and as Jim likes to say, even transform learning through the use of technology. So there was this underlying will and belief system in place. (Bob Thomas, interview, April $12,2007)$ 
To create a supportive context for teacher learning, you need to "line up your ducks," drawing on the resources that you have and infusing them with a vision for the future (Bob Thomas, interview, April 12, 2007). The idea for the New Frontiers School Board's [NFSB] teacher action research project was the inspiration of Jim Sullivan (Director of Educational Services at NFSB) and Bob Thomas (Pedagogical Technology Consultant at NFSB). NFSB is situated on Montreal's south shore.

\section{In Bob's words,}

We started small ... with a lab of 17 laptops ... the rationale was that you create the winning conditions in which integration of technology can produce results. We [Jim and I] were of the belief that technology was positive. There was something that was potentially quite transformative for learning, but we wanted to do it in our own context, within our own schools, with our own constraints, and to see that we could make it work. But at the same time, we wanted to remove some of the obstacles like: access to enough technology, access to stable, functional, working technology, access to support for technology. So by creating these winning conditions and putting in all the enablers and removing the obstacles, we wanted to see, okay, what then? Now would they make an impact and how? (Bob Thomas, interview, April 12, 2007)

"Learning with Laptops" has been in place in the school board for three years. The school board initially secured funding for teacher release time by obtaining funds made available through a special governmental measure. The school board purchased the laptops and necessary peripherals, beginning with the 17 machines, which rotated through three different grade six classrooms for fifty days at a time throughout each school year from 2004 to 2005. Then they purchased twenty-three additional computers, for a total of forty laptops as well as a camcorder, two digital still cameras, four webcams, a hard drive, a dedicated server, four wireless routers, laptop transport cases and student backpacks. Two schools also purchased laptops (two each) with their school budgets, while the principals of two other schools who were supportive of the project's goals bought Smartboards for their teachers. At the present time, enough laptops exist to provide class sets to three classrooms over the entire school year.

Teams of teachers were invited to submit proposals to the board. The school board was looking for iniatives that would create complex learning situations or longitudinal projects based on meaningful and regular use of the laptops. In this latest call for proposals (the project was due to begin in September 2006), three teams were 
successful in their applications. Seven teachers became participants in the teacher action research project. Three different schools are currently involved. Four teachers teach Cycle Three (Grade 6); within the teaching teams, one teacher instructs in English, the other in French. Another three teachers teach Grade 7 students in Secondary One; two teachers teach in English and one in French. For the first time in the Laptops Program, elementary and secondary teachers are sitting at the same table. Furthermore, of the four elementary teachers, two are peer coaches, which represents a Board initiative to build teacher capacity through literacy coaching by having two teachers from the first Laptops project participate in the second round. Literacy coaching has been receiving increasing approbation as a way for teachers to motivate the practices of their fellow teachers (Bauman, 2007). The coaches are Kelly and Manuela.

Like the school board and LWL, the CLCF McGill research team focuses on teacher action research, using methodological tools that will assist teachers with documentation of and reflection on their inquiry with technology. Research team members conduct regular reflective interviews with the teachers, engage in participant observation in classrooms, and provide opportunities for teachers to view and reflect on videotaped lessons. The key to sustaining teacher reflection and momentum, however, rests in the in-person and on-line forums; the in-person forum takes place one day a month. Bob Thomas leads these sessions, with the McGill team taking the lead for part of the morning or providing support for activities that Bob and Teresa (member of the McGill team) have jointly agreed upon. Teachers respond to writing prompts, complete surveys, write and discuss literacy autobiographies; in short, they reflect on where they have come from and where they are going, and how they can support one another in this learning endeavor. In the teacher blog, they continue their conversations, sharing practices and posting examples from classroom projects (in the planning stages or already implemented). Multiple avenues for individual, small group and whole group exploration and reflection exist.

\section{Teacher Conversation}

K: (Kelly) Well, anything about technology interests me, so, that was a nobrainer. I definitely wanted to be part of it, but I wasn't sure how it would turn out. I knew a bit about computers, but not a lot, and I had never used computers with children above grade three. No-sorry, that's not true, I did. 
M: (Manuella) Well ... in the lab.

K: I did it with the older children but it was only part-time.

M: We had a mobile, like a lab on wheels, with PCs, or laptops, and I had tried that. But they weren't wireless and-it was a fiasco, every time I borrowed them and brought them to class it was not a nice experience ...

T: (Teresa) How come?

M: Well, for one, there was always something breaking down.

K: $\quad$ No support. No one there could help.

M: No technician. They were not very good computers, they weren't state of the art, there was always something wrong. And just the wires, and figuring out how to connect them-so, I just gave up, then I thought, maybe with this, if somebody could be there with me-l [would spend] all lunch hour setting them up sometimes to make sure they would work, and then still, something would happen. So I didn't feel very good ...

K: And that was one of the conditions of the Learning with Laptops Project. In the outline it said you would be supplied with state of the art technology as well as support from the board. If we hadn't had the support and had just been given the laptops like previous[ly], I wouldn't have accepted it. (Kelly \& Manuela, interview, April 12, 2007).

\section{Engaging Learners}

The word motivation comes from the Latin movere, meaning "to move." Learning cannot be forced or controlled by external sources or pressures (Hall, 2005). Teachers need to exert an influence over change (Kimonena \& Nevalainen, 2005). Collaboration with colleagues plays a key role (Butler et al., 2004; Little, 2002; Pianfetti, 2001), creating spaces for professional growth by offering colleagues the opportunity to share and reflect on practices and co-construct knowledge and conceptual frameworks (Kimonena \& Nevalainen, 2005). Engaged teachers want to engage their students; they want to know what moves their students to feel, think and behave in ways that relate positively to learning. As Doucet (2006) argues, teachers can develop deeper insights into student engagement by also delving into their past experiences as students. 
In the following section, we connect some of our research data to principles of teacher and student engagement that we identified in the existing body of literature. We wanted to see whether what the key players in the LWL project identified as best practice was supported by the literature.

The research on teacher engagement centers on three principles: the provision of support; opportunity for teacher reflection on past and present practices; and teacher openness to new learning. The student engagement literature, which draws on socio-cognitive models, can be distilled to five principles: ability and efficacy (belief in an ability to do something); control and autonomy (a belief in being able to do it on one's own); intrinsic motivation (an interest in the activity for its own sake); subjective task value (an activity is viewed as important); and goal orientation (a belief that engaging in the activity will lead towards achieving a goal). Each of the teacher and student principles is taken up in turn, with examples provided from the project. What has become clear, during the course of the first year of the project, and building on the previous iteration, is that teacher engagement "moves" student engagement, which moves teacher engagement, thus generating a reciprocal feedback loop of engaged learners: teacher and student.

Principle 1: Teachers need support in their learning process, especially from administrators (Hall, 2005; Pianfetti, 2001). Working with others generates the energy to sustain momentum, especially when challenges are faced (Butler et al., 2004).

Example: "There is first of all the problem of the opening, namely, how to get us from where we are, which is, as yet, nowhere, to the far bank" writes novelist J. M. Coetzee (2003, p. 1). Bob Thomas talked about a project in which he had once invested a great deal of time and effort. The political tides changed and the group dissipated, leaving Bob at loose ends, and wondering what happened to all the momentum and work. Even if learning begins in a state of uncertainty, once a journey begins, there needs to be a belief that it will go somewhere. To have trust in the conviction that it will depends on active participation, but it also relies on concrete and sustained support throughout the journey.
T: (Teresa) So what's kept you in the project?
K: (Kelly) Bob ... (laughing)
M: (Manuela) The support.
K: Yes, the support ...
M: The support and the fact that we keep learning; it keeps changing. (Kelly \& Manuela, interview, April 12, 2007) 
When teachers are provided with support, as through a teacher action research framework, they are more willing to "grapple with their own journey" (Bob Thomas, April 12, 2007) and to "keep learning" (Manuela, April 12, 2007). Teachers rely on the support of administrators; they also rely on one another. The key support provided to teachers in the LWL project has come from Bob Thomas who, as the pedagogical technology expert, is committed to honouring teacher knowledge by becoming intimately familiar with teacher action research methodologies.

Principle 2: To be effective, teacher incorporation of technology must come about through an experiential process of action and reflection. Teachers need time and ongoing opportunities to change their pedagogical beliefs and develop new conceptual knowledge as it relates to their practice (Cochran-Smith \& Lytle, 1993).

\section{Example:}

K: (Kelly) Bob always stressed, 'Stop thinking about the programs you have, think about what is it you have to teach the students' -

M: (Manuela) Pedagogy.

K: And then, how could the technology facilitate it? Whereas in the first year, I think I was still stuck on ... okay, I want to use CMAP, what will I do with CMAP? Instead of thinking, well I want to do a graphic organizer, and then thinking about the technology. So for sure my planning has changed a lot and there's so many things now that we can do as opposed to the first two years because we realize all the different aspects.

M: The way we plan has changed-it's not well, how can I use this program, but, this is what I want to accomplish with the kids. It's pedagogy, and then how I am going to use the tool. Which would be the easiest, should I have them sharing in a forum, or a blog, or ...? That's what keeps us going. (Kelly \& Manuela, interview, April 12, 2007)²

One example of an engaged use of CMAP came from another LWL classroom. The grade 6 students were working on language arts exams, one portion of which involved designing and marketing a product. On the day on which we videotaped this activity, the teacher was modeling CMAP for the first time on the Smartboard, introducing the strategy so that students could revisit and remap the marketing plans for their products by distilling the most salient points and then rephrasing these, using vivid, detailed language. As we circulated throughout the classroom, the students readily took to the task, while the teacher periodically reminded them to focus on the language they were using and not be distracted by 
fonts or other display aspects. Students demonstrated how their language in the CMAP was more detailed than what they had provided in web displays in their exam booklets. Once they had completed their CMAP, they could then explore other options within the program, including how to use surface features (like glitter letters) to attract the eye (Classroom videotaping, May 18, 2007). Technology does not drive teaching; pedagogy informs the incorporation of new technologies in the classroom. It takes time, practice, and dialogue with others to creatively and authentically incorporate technology into pedagogy.

Principle 3: Teachers need to bring a willingness to learn and explore changes to their practices (Butler, et al., 2004; Van Eekelen et al., 2006).

Example: By introducing the teachers to new practices, usually in the afternoons of the monthly meetings, Bob challenged the teachers to not only see technology within a wider lens, but also to experience it within the session, put it to work, and thus expand their notions of literacy.

Some teachers have used technology as a reward (you know, when you do it conventionally and then you can do it as a reward-[now you're free to] go on the computer). Or when you've written your rough draft on paper, then you can put in the computer. And that's not allowing anything to be transformative ... We've seen ... glimmers of ... transformations when the kids can use technology to write to an authentic audience, when they can blog and get responses from the outside or they can videoconference with other people-a quote-unquote, authentic audience-or somebody out there that they can really feel that they're being listened to, that they're publishing for a purpose. (Bob Thomas, interview, April 12, 2007)

Technological innovations have kept Bob and the teachers on their toes. As Manuela said, "we keep learning, and it keeps changing" (Interview; April 12, 2007). Kelly is now looking at how she can use iWeb to create personal web pages, while Manuela is interested in podcasting and how that might lead to a student-produced radio show. The other teachers, having undergone the first iteration of $L W L$, have acquired preferred ways of using the technology (as well as those uses they will avoid) but all have their eye on the next innovation that they can try out for its pedagogical possibilities (Teacher Meeting; June 14, 2007).

Principle 4: To be engaged, students need to believe they can do the task (Ability and efficacy) When students believe that they can and will do well, they are more likely to be 
motivated to engage in a particular task (Eccles, Wigfield \& Shiefele, 1998). Feelings of competence are supported in students when they are presented with optimally challenging tasks, including high challenging tasks with instructional support (Deci \& Ryan, 1992; Miller \& Meece, 1999; Pressley, 2002).

Example: Manuela brings a deep interest in comics from her own childhood (Teacher meeting; October 19, 2006). The students also bring a familiarity with animation and cartoons, and some bring a facility with using digital media, but not necessarily in the context of using a software program called "Comic Life." Manuela was using the program with the Grade 6 students; they were co-creating a yearbook. She tried it out first, producing a "Comic Life" page using photographs and dialogue based on her own family; this practice is consistent with that of the other teachers and the second and third principles (see above). She then presented her project as a model to her students.

As a class, Manuela brainstormed with the students about the possbile topics for the yearbook comics and recorded their ideas on the blackboard. Once the students started bringing in digital photographs as well as scanned pictures and other artifacts from home, and writing the accompanying captions, Manuela discovered that their writing was formulaic and banal. She then developed peer-editing lessons using the laptops, to teach students how to write in an engaging and varied manner in their dialogue boxes. After all, this "Comic Life" was to be a remembrance of their elementary school days, containing their most treasured memories and photographs. The dialogue needed to be at its "comic" best.

Students were confident about their ability to use the software but were appropriately challenged to use the program to deepen their competence as second language speakers, readers and writers. Their confidence was also built up by Manuela, who experimented with the program, observed her students, and used pedagogy to address limitations so as to instill in students belief in their competence to use the laptops to convey an important message in French.

Principle 5: To be engaged, students need to believe that they can do it themselves (Control and autonomy) Student autonomy is supported in classrooms where learners exercise some choice and control. In particular, these classrooms provide opportunities for open-ended activities (Turner, 1995), meaningful choices (Pressley, Rankin, \& Yokoi, 1996), goal setting (Locke \& Latham, 1990), and self-monitoring and evaluation (Zimmerman, 2001). They also create environments that are supportive and nonthreatening (Perry \& Drummond, 2002). 
Example:The students in Kelly and Manuela's classrooms spend time in one teacher's classroom in the morning and then switch, crossing the hallway in the afternoon. Students recognize the warmth and collegiality in their teachers' partnership, which supports their autonomy as teachers. This recognition positively affects student engagement.

K: (Kelly) Well, if we were not to be partners next year ... [I] don't even think about that ... I can't picture who else would actually be as excited and motivated and willing ...

M: (Manuela) And the kids really capture that, they're really in tune with that because they know that sometimes certain things are supposed to be given to [the] homeroom teacher and they don't even remember what homeroom they're in sometimes. They give me papers that are supposed to go with Kelly, or they don't know the journals are kept with [whom] - they just flow. They go back and forth, and if it were up to us there would be no walls, just a centre pod where they keep all their stuff and just go and get it. And the kids see our cooperation, collaboration ... And I think they get that and they understand that that's the way we work and that's the way you have to work. You can't be an individual working by yourself ... you're here in a society ... I think that establishing that takes time and the kids already feel that from day one. They know it before they come in, they know that we're a pair. (Kelly \& Manuela, interview, April 12, 2007)

The students develop autonomy by their movement back and forth between classrooms. They construct a notion of autonomy that is rooted in collaboration, as their teachers work together to achieve greater autonomy in using the laptops within their own pedagogy and for the students' benefit.

Principle 6: To be engaged, students need to be interested. (Intrinsic motivation) Intrinsic motivation is characterized by engaging in an activity for its own sake. Intrinsically motivated individuals are more likely to demonstrate sustained involvement in a task (Stipek, 2002) and will have better comprehension and conceptual understanding (Schiefele, 1996). Students have been shown to demonstrate higher levels of this engagement in classrooms that provide stimulating and interesting tasks (Stipek, 2002) and when presented with material and tasks that are personally meaningful (Guthrie \& Wigfield, 2000) and that incorporate real-world interactions (Aarmouste \& Shellings, 2003; Wigfield, Guthrie, Tonks \& Perencevich, 2004). Students show greater interest and involvement when teachers demonstrate caring (Murdoch \& Miller, 2003; Wentzel, 1997). 
Example: The following excerpt provides a good example of how as students' interest quickened given the opportunity to explore the new media, so too did their teacher's as she observed them figuring things out on their own.

K: (Kelly) ... when I had them use Apple Works to do a slideshow on a book they had read for literature circles, what I showed them was so basic, and I thought, okay, well, they'll each have three slides, one is about character, one about setting, one about plot-but they did so much more, they were finding out about biography, they were finding out about the author, they were going online to get maps, they wanted to put sound files in, but I didn't know how to do that and they were trying to figure it out [themselves]. (Kelly, interview, April 12, 2007)

Principle 7: Students are engaged in learning when they perceive it is important to them (Subjective task value) An individual's decision to perform a task-and the amount of effort that individual is willing to spend on it-depends on how much he or she values the opportunity to engage in the task as well as how much he or she values the potential rewards for performing the task well (Eccles et al., 1983). A student's value of an activity is heightened when the task is perceived to be relevant and has realworld significance (Bruning \& Horn, 2000; Mitchell, 1993).

Example: Kelly explained:"I read, I write, I go to LWL meetings, I go to school (at university), we peer edit one another's work; in short, we live learning." Modeling is a way for the teachers to transmit a passion for learning, thus ascribing value to the control and autonomy that can come about as a result of engaging in a learning process, leading students to think: "If my teacher is doing this, then it must be important."

M: (Manuela) Modeling is always really what we do, regardless if it's electronic, or on the board.

K: (Kelly) But you model minimally, so they can use their imaginations, because if you show them too much, then you just get a carbon copy of what you showed them. (Kelly \& Manuela, interview, April 12, 2007)

Students need to perceive their own value in the activity, such as when Kelly's class read aloud Macbeth. Through conducting research on the Internet as well as constructing presentations based on viewing the plot from another character's point of view, students became involved in this well-trod tale and took it on as their own. The class project began, though, with Kelly's interest in valuing digital storytelling with a traditional, and favourite, text. 
Principle 8: Students feel engaged when they perceive that doing the activity takes them somewhere (Goal orientation) When a student is interested in the knowledge to be gained from engaging in a particular task, he or she is said to have a learning goal orientation (Ames, 1992). Many goal theorists say that learning goals are more beneficial in engaging students than performance goals (Wigfield et al., 1998), in which students become more concerned with outperforming peers. Students are more likely to adopt a learning goal orientation in classrooms that create environments that are both cognitively and affectively supportive (Meyer \& Turner, 2002). Student motivation is also enhanced in classrooms that use collaborative groups in which students are allowed to pursue social goals (Stevens \& Slavin, 1995; Nichols, 1996).

\section{Example:}

K: (Kelly) I always find them engaged when they're on the laptop-

M: (Manuella) They're always on task ...

K: ... For one, it's because they really have to concentrate because sometimes they have to hear-if they don't have headphones they have to be closer to their laptops and they seem to block out distractions. The writing-you know with a book, they can turn around with their book or move-with the laptop if they're reading, they really have to be focused on it, and they automatically seem to be blocking things out now. And I even noticed last week, two kids got up-they didn't even ask - and moved to the book corner to sit on the floor, and I'm sure it was because the kids around them were talking and they just wanted to be more secluded. But we can put them out to work in the hallway, sitting on the floor with their laptops and they're never doing something else, they're always just focused on their work ... right?

M: I never thought that it would be like that when we first started the project. I really thought we would have to monitor, to make sure that they weren't doing something off-task. (Kelly \& Manuela, interview, April 12, 2007)

Their principal provided corroboration for this focused engagement: "Never have I walked into a grade six classroom with those laptops in the room where they are just bored or disruptive, not focused" (Principal interview, February 22, 2007; emphasis in the original). The teachers have continued to reflect on why the students are focusing more, and working together to create a climate in which it is possible to do so. They attribute part of this development to their own achievement of their goal to transform the technology into pedagogy. 
K: They don't even know there are games on there yet, they haven't explored it ... the chess, there's all kinds of games in there, really, they haven't figured it out. Last year they did, but not this year.

M: No.I think this year [they're] even more [focused], because we're more comfortable with the technology. The pedagogy behind it is stronger so they're on task because they have something to accomplish, something to create, something to do. They don't have the time, or the desire ... (Kelly \& Manuela, interview, April 12, 2007)

\section{Conclusion}

Learning does not result from the mere placement of the right ingredients in a pot: teachers, students, tools. Teachers and students discover new things by engaging in dynamic, impassioned, and sustained conversations with each other. Engaged teachers demonstrate a willingness to learn by asking questions, sharing experiences, and listening and responding to one another and to their students. To engage in learning, teachers need to know they are being heard, that the activity they are undertaking is meaningful and that they have something important to contribute to the process. Students are inspired to take risks and think creatively when their teachers do.Teachers and students may feel defeated when they are overchallenged, or bored when underchallenged. One of the ongoing goals of Learning with Laptops has been to keep both teachers and students fully committed and interested in what new technologies can contribute to their learning. This article has only touched the "tip of the iceberg" in presenting data on teacher engagement that has a direct bearing on student engagement.

Questions and challenges remain, and will be pursued in the second year of the project. How do new technologies influence engagement in learning across the curriculum? Are certain areas of learning being neglected because others are being overly prioritized? Are all students equally engaged by the new technologies? (An informal survey that Manuela and Kelly conducted in their classrooms in May, 2007 suggests that most definitely are, but some prefer reading and writing on paper.) Are educators gazing starry-eyed at PowerPoint ${ }^{\circledR}$ presentations when other work may be less glitzy but more developed? Is form being valued over content? What happens to student and teacher engagement when the tools are withdrawn or diminished? These questions are part of "grappling" with the LWL journey. Central to sustaining teacher engagement, though, has been the use of conversations to move through 
problems, rather than avoiding them so as to create a "lovely story" that does not ring true with teachers' experiences (Pitt \& Britzman, 2003).

"Line up your ducks." While there are many ducks to line up, the ones that Kelly, Manuela and Bob identified as absolutely crucial for engaging teachers as learners were: support and new experiences. Learners need opportunities to develop competence and exercise their creativity through experiencing learning for themselves. Learners also need to be supported in their learning, through sharing ideas, modeling and guidance, cognitively challenging contexts, encouragement and caring. Engagement, Smagorinsky and O'Donnell-Allen (1998) emphasize, is more social than individual, "nested" in interactions between people as well as in the cultural and social histories that learners bring (p. 552).

While Jim Sullivan envisaged that new technologies would transform students' learning, he didn't anticipate the degree to which teachers would be transformed as well:

What came as a surprise to me, thanks to the leadership of Bob Thomas and to a team of dedicated and talented teachers, was the fact that student use of technology not only transformed learning but teaching as well. Conversations with the teachers involved in the LWL project were very different from conversations with their peers. Teaching strategies were more focused, evaluation was built into the process, differentiation of instruction was discussed and alternatives were planned in the lesson, based in individual needs. These teachers were not only enthusiastic but [also] empowered! The contribution of the research team from McGill has helped us to verbalize what was happening. (Jim Sullivan, personal communication [E-mail], April 29, 2007)

For those who have been involved in the LWL project, they know that it is really the other way around: that student engagement with the laptops likely would not have happened without the teachers learning together, receiving support for that learning, and co-constructing and scaffolding learning with their students. As we have seen from the approach to professional development taken within this innovative and sustained school-university partnership, key interactions occur between teachers, as well as between teachers and a leader. Teachers need be allowed to feel supported as learners and teachers alike:"teachers (as learners) first." 


\section{Notes}

1. The research for "Changing Literacies, Changing Formations" (SSHRC, 2006-2009; 410-2006-0161) has kindly been made possible through a Social Sciences and Research Council funding. "Learning with Laptops" is supported by the New Frontiers School Board.

2. CMAP is a mind mapping software that allows students to organize ideas and establish linkages between them. As an electronic tool, students can manipulate ideas visually, without any arduous recopying or starting over. For more on CMAP, see: http://cmap.ihmc.us.

\section{References}

Ames, C. (1992). Classrooms: Goals, structures, and students motivation. Journal of Educational Psychology, 84, 261-271.

Bauman, A. (2007, March). Literacy coaching: An idea whose time has come. The NCTE [National Council of Teachers of English] Council Chronicle, 16(3), 1, 10-11.

Brandt, D. (1992). Remembering writing, remembering reading. College Composition and Communication, 45, 459-479.

Brown, D. (1999). Promoting reflective thinking: Preservice teachers' literacy autobiographies as a common text. Journal of Adolescent and Adult Literacy, 45, 402-410.

Bruning, R. \& Horn, C. (2000). Developing motivation to write. Educational Psychologist, 35, 25-37.

Buckingham, D. (2000). After the death of childhood: Growing up in the age of electronic media. Cambridge: Polity Press.

Burrington, B. \& Sortino, S. (2004). In our real world: An anatomy of documentation. In J. Hendrick (Ed.), Next steps toward teaching the Reggio way: Accepting the challenge to change (pp. 224-237). Upper Saddle River, NJ: Pearson Prentice Hall.

Butler, D. L., Novak Lauscher, H. Jarvis-Selinger, S. \& Beckingham, B. (2004). Collaboration and self-regulation in teachers' professional development. Teaching and Teacher Education, 5, 435-455.
Butler-Kisber, L., \& Portelli, J. (Eds.). (2003). McGill Journal of Education; Special Issue: Student Engagement.

Chawla, L. (1994). In the first country of places: Nature, poetry, and childhood memory. New York: State University of New York Press.

Cochran-Smith, M. \& Lytle, S. L. (1993). Inside/Outside: Teacher research and knowledge. New York: Teachers College Press.

Cochran-Smith, M. \& Zeichner, K. M. (Eds.). (2005). Studying teacher education: The report of the AERA panel on research and teacher education. Washington, DC: American Educational Research Association \& Lawrence Erlbaum Associates.

Coetzee, J. M. (2003). Elizabeth Costello. London: Secker \& Warburg. (Originally published 1999).

Deci, E. \& Ryan, R. (1992). The initiation and regulation of intrinsically motivated learning and achievement. In A. Boggiano \& T. Pittman (Eds.), Achievement and motivation: A social-developmental perspective (pp.9-36). Cambridge, England: Cambridge University Press.

Dewey, J. (1963). Experience and education. New York: Collier Books (Originally published 1938 by Kappa Delta Pi).

Doucet, R. (2006). Student engagement: Understanding the science and the stories of motivation. Unpublished master's thesis, 
McGill University, Montreal, Quebec, Canada.

Eccles, J, Adler, T., Futterman, R., Goff, S., Kaczala, C., Meece, J., \& Midgley, C. (1983). Expectancies, values, and academic behavior. In J. T. Spence (Ed.), Achievement and achievement motives: Psychological and sociological approaches (pp. 75-146). San Francisco: Freeman.

Eccles, J. S., Wigfield, A., \& Schiefele, U. (1998). Motivation to succeed. In W. Damon (Series Ed.), \& N. Eisenberg (Vol. Ed.), Handbook of child psychology ( $5^{\text {th }}$ ed., Vol. 3, pp.1017-95). New York: Wiley.

Gadamer, H. G. (1975/1998). Truth and method. New York: Continuum.

Gatto, J. T. (2000). A different kind of teacher: Solving the crisis of American schooling. Berkeley, CA: Berkeley Hills Books.

Gee, J. (2003). What video games have to teach us about learning and literacy. New York: Palgrave Macmillan.

Glazer, C., Abbot, L. \& Harris, J. (2004). A teacherdeveloped process for collaborative professional reflection. Reflective Practice, 5 (1), 33-46.

Goodenough, E. (2004) Introduction. In E. Goodenough (Ed.)., Secret Spaces of Childhood (pp. 1-16). Ann Arbor, MI: The University of Michigan Press.

Guthrie, J. T. \& Wigfield, A. (2000). Engagement and motivation in reading. In M. Kamil \& P. Mosenthal (Eds.), Handbook of reading research (vol. 3, pp. 403-422). Mahwah: Erlbaum.

Hall, C. (2005). Theorising changes in teachers' work. Canadian Journal of Educational Administration and Policy, 32. Retrieved May 9, 2005, from http://www.umanitoba.ca /publications/cjeap/articles/noma/theori sing.change.html

Jenlink, P. M., \& Kinnucan-Welsch, K. (2001). Case stories of facilitating professional development. Teaching and Teacher Education, 17, 705-724.

Jones, O., Williams, M. \& Fleuriot, C. (2003).'A new sense of place?': Mobile 'wearable' communications technology devices and the geographies of urban childhood. Children's Geographies, 1(2), 165-180.
Katch, J. (2001). Under deadman's skin: Discovering the meaning of children's violent play. Boston: Beacon Press.

Kemmis, Stephen, \& McTaggart, Robin (2000). Participatory action research. In Norman Denzin \& Yvonne S. Lincoln (Eds.), Handbook of qualitative research (pp.567605). Thousand Oaks, CA: Sage.

Kimonena, E. \& Nevalainen, R. (2005). Active learning in the process of educational change. Teaching and Teacher Education, 21,623-635.

Kincheloe, J., Slattery, P., \& Steinberg, S. (2000). Teachers as researchers. In Contextualizing teaching: Introduction to education and educational foundations (pp. 267-298). New York: Longman.

Lankshear, C., \& Snyder, I. (2000). Teachers and technoliteracy: Managing literacy, technology and learning in schools. Crows Nest, Australia: Allen \& Unwin.

Little, J.W. (2002). Locating learning in teachers' communities of practice: opening up problems of analysis in records of everyday work. Teaching and Teacher Education, 18, 917-946.

Locke, E. \& Latham, G. P. (1990). A theory of goal setting and task performance. Englewood Cliffs, NJ: Prentice Hall.

Mackey, M. (2002). Literacies across media: Playing the text. London: Routledge Falmer.

Mackey, M. (2003). At play on the borders of the diegetic: Story boundaries of narrative interpretation. Journal of Literacy Research, $35,591-632$

Mackey, M. (2006). Digital games and the narrative gap. In D. Buckingham \& R. Willett (Eds.), Digital generations: Children, young people, and new media (pp. 33-48). Mahwah, NJ: Lawrence Erlbaum.

Meek, M. (2004). Readings about reading. Changing English, 11(2), 307-17.

Meyer, D. K. \& Turner, J. C. (2002). Discovering emotion in classroom motivation research. Educational Psychologist, 37, 107114.

Miller, S. D. \& Meece, J. L. (1999). Third graders' preferences for reading and writing tasks. Elementary School Journal, 100, 19-35. 
Mitchell, M. (1993). Situational interest: Its multifaceted structure in the secondary school mathematics classroom. Journal of Educational Psychology, 85, 424-436.

Nichols, J. D. (1996). Cooperative learning: A motivational tool to enhance student persistence, self-regulation, and efforts to please teachers and parents. Educational Research and Evaluation, 2, 246-260.

Paley, V. G. (1981). Wally's stories. Cambridge, MA: Harvard University Press.

Paley, V. G. (2004). A child's work: The importance of fantasy play. Chicago: University of Chicago Press.

Perry, N. \& Drummond, L. (2002). Helping young students become self-regulated researchers and writers. The Reading Teacher, 56, 298-311.

Pianfetti, E. (2001). Teachers and technology: Digital literacy through professional development. Language Arts, 78(3), 255262.

Pitt, A., \& Britzman, D. (2003). Speculations on qualities of difficult knowledge in teaching and learning: An experiment in psychoanalytic research. Qualitative Studies in Education, 16(6), 735-776.

Pressley, M. (2002). Reading instruction that works: The case for balanced teaching. New York: Guilford Press.

Pressley, M., Rankin, J., \& Yokoi, L. (1996). A survey of instructional practices of primary teachers nominated as effective in promoting literacy. Elementary School Journal, 96, 363-383.

Russell, M., Bebell, D., O'Dwyer, L. \& O'Connor, K. (2003). Examining teacher technology use: Implications for preservice and inservice teacher preparation. Journal of Teacher Education, 54(4), 297-310.

Schiefele, U. (1996). Topic interest, text representation, and quality of experience. Contemporary Educational Psychology, 21, 3-18.

Smagorinsky, P., \& O'Donnell-Allen, C. (1998). The depth and dynamics of context: Tracing the sources and channels of engagement and disengagement in students' response to literature. Journal of Literacy Research, 30(4), 515-559.
Statistics Canada. (2004). Connectivity and learning in Canada's schools. Ottawa, ON: Ministry of Industry.

Stevens, R. J. \& Slavin, R. E. (1995). The cooperative elementary school: Effects on students' achievement, attitudes, and social relations. American Educational Research Journal, 32, 321-351.

Stipek, D. (2002). Motivation to learn: Integrating theory and practice ( $4^{\text {th }} \mathrm{Ed}$.). Boston: Allan \& Bacon.

Strong-Wilson, T. (2006). Touchstones as sprezzatura: The significance of attachment to teacher literary formation. Changing English, 13(1), 69-81.

Strong-Wilson, T. (2007). This Issue. Theory into Practice, 46 (1) (Reggio Emilia special issue; Guest editor:Teresa Strong-Wilson).

Turner, J.C. (1995). The influence of classroom contexts on young children's motivation for literacy. Reading Research Quarterly, 30, 410-441. Van Eekelen, I.M., Vermunt, J.D. \& Boshuizen, H.P.A. (2006). Exploring teachers' will to learn. Teaching and Teacher Education, 22, 408-423.

Wentzel, K. R. (1997). Student motivation in middle school:The role of perceived pedagogical caring. Journal of Educational Psychology, 89, 411-419.

Wheatley, M. J. (2002). Turning to one another: Simple conversations to restore hope to the future. San Francisco: Berrett-Koehler Publishers.

Wigfield, A., Eccles, J. S., \& Rodriguez, D. (1998). The development of children's motivation in school contexts. In A. Iran-Nejad \& P. D. Pearson (Eds.), Review of research in education (Vol. 23, pp. 73-118). Washington, DC: American Educational Research Association.

Wigfield, A., Guthrie, J.T., Tonks, S. \& Perencevich, K. C. (2004). Children's motivation for reading: Domain specificity and instructional influences. Journal of Educational Research, 97, 299-309.

Zimmerman, B.J.(2001).Theories of self-regulated learning and academic achievement: An overview and analysis. In B. J. Zimmerman \& D. H. Schunk (Eds.), Self-regulated learning and academic achievement ( $2^{\text {nd }}$ ed., pp. 1-37). Mahwah, NJ: Erlbaum. 


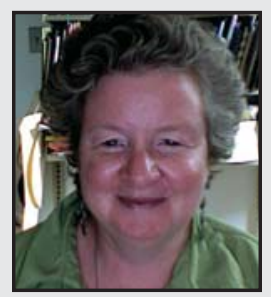

Teresa Strong-Wilson is Assistant Professor in the Department of Integrated Studies in the Faculty of Education at McGill University, Montreal, Quebec. She is interested in changing literacy formations, early childhood, children's literature, social justice and Indigenous education, and teacher education. Her primary area of investigation is the influence of stories on identity formation. She has published in such journals as: Changing English, Children's Literature in Education, Educational Theory, International Education, Journal of Curriculum Theorizing, Reflective Practice, Studying Teacher Education, and Theory into Practice. A forthcoming book, published by Peter Lang, is called Bringing Memory Forward: Storied Remembrance in Social Justice Education with Teachers.

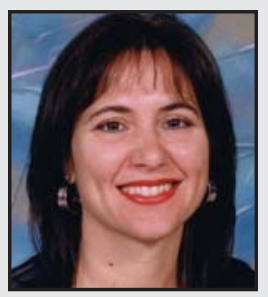

A teacher since 1993, Manuela Pasinato has been teaching Elementary Cycle 3 level in a in a bilingual setting for over 10 years. Currently tackling the French language, she has also enjoyed teaching English and French as a second language. After exploring porfolio use and student led conferencing, integrating new technology in her practice is what is now revolutionalizing her experience as a teacher, and motivating her students.

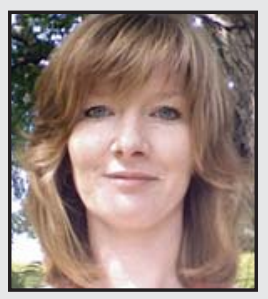

Kelly Ryan is a Cycle 3 Elementary English teacher from New Frontiers School Board. She has been teaching for ten years at St. Willibrord Elementary School in Chateauguay. Kelly and her French teaching partner, Manuela Pasinato, have been involved in a Learning With Laptop Initiative for four years. Kelly's main interests include the use of technology in the classroom, such as creating i-movies, digital stories, and graphic organizers. A second interest lies in the use of portfolios for assessing and tracking student learning. 


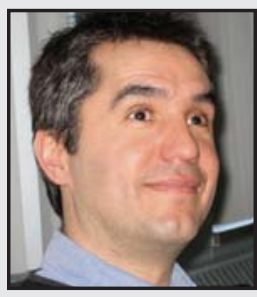

Bob Thomas is the local RÉCIT consultant for New Frontiers School Board and project coordinator of the New FrontiersMcGill teacher action research partnership "Learning with Laptops." Bob is a former Middle and High School teacher, and has also worked as a Vice-Principal. He has been working with teachers and students integrating technology into the classroom since 2002.

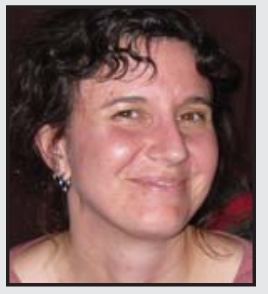

Nicole Mongrain is currently completing her Masters of Arts in Education at McGill University in Montreal. She works as a research assistant on the "Changing Literacies Changing Formations" project. She taught at the elementary level for 6 years in Northern Ontario.

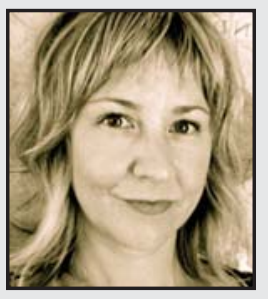

Maija-Liisa Harju is a doctoral student at McGill University, Montreal, researching crossover literature as a bridge between children's and adult culture. She also teaches a Children's Literature course investigating the crossover phenomenon in McGill's Department of Education. Her latest publication "Encouraging Grand Conversations: Using Crossover Picture Books to Open Up New Dialogues for Death Education" can be found in a forthcoming 2007 issue of the journal English Quarterly.

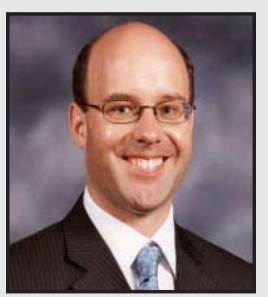

Richard Doucet teaches Grades Three and Five at Selwyn House School in Westmount, Quebec. He has an M.A. in educational studies from McGill University, and his research interests focus on student engagement, literacy, and narrative inquiry. In both research and in practice, Richard is particularly interested in the ways in which new technologies and other media support student motivation and achievement in literacy. 


\section{LINK TO:}

http://recit.csnewfrontiers.qc.ca/lwl/Welcome.html http://www.hebdos.net/lsc/archives/articles.asp?article_id=167848\&chaine= learning\%20with\%20laptops

http://cmap.ihmc.us. 